\title{
The Effects of the Korean Wave (Hallyu) Star and Receiver Characteristics on T.V Drama Satisfaction and Intention to Revisit
}

\author{
Won-jun, Lee \\ Cheongju University, Korea \\ marketing@cju.ac.kr
}

\begin{abstract}
In recent years, the popularity of Korean pop culture in Asian nations is increasing and the Korean Wave becomes a new cultural trend. This study examines the consumer behavior of Chinese tourists visiting Korea and investigate factors influencing Korean television drama satisfaction and intention to visit Korea again. To empirically test the hypotheses, questionnaires had been collected and path analysis was performed.

The results of the study indicate that the attractiveness and credibility of Korean stars affect T.V drama satisfaction while the commitment of fans affects drama satisfaction positively. Also, satisfaction affects intention to revisit Korea positively.
\end{abstract}

Keywords: Korean wave, Hallyu, Tourism, Culture Diffusion, Iintention to Revisit

\section{Introduction}

Globalization has played an increasingly critical role in every area of life, society, and culture is not an exception. The Korean Wave (or 'Hallyu' in Korean) is a very popular cultural phenomenon among Asian consumers today. For instance, the Korean singer 'PSY' and his song 'GangNam Style' was the most watched YouTube video by 2012 (Dobuzinskis, 2012). Now the Korean Wave has gained increasing recognition in China, East Asia, Southeast Asian nations, including Taiwan, Japan and Hong Kong (Hong and Kim, 2013). The Korean Wave also made its noteworthy entrance in Latin America (Ko et al., 2014).

This new cultural trend also has a significant impact on the Korean economy through exports of its product and increased tourism (Lee, 2015; Hogarth, 2013). The number of foreign tourists visiting Korea because of the Korean Wave has increased steadily and the cultural phenomenon results in increased purchase of the related product such as cosmetics, fashion, and Korean cuisine by foreign customers (Yu et al., 2012).

However, academic researches about the Korean Wave are very rare until now. In this study, we try to understand the importance of Korean Wave stars' characteristics and the Korean Wave fan's characteristics and their effects on the attitude and behavioral intention. Those impacts on the Korean drama satisfaction and revisit intention of Korea are analyzed empirically to suggest managerial implications for the Korean Wave related industry.

\section{Theoretical Background}

\subsection{Diffusion of Culture}

Diffusion is both transmission process and adoption process of new product and ideas throughout social systems (Rogers, 2003). Diffusion type can be classified according to what you transmit. There are political diffusion, economic diffusion and cultural diffusion ( $\mathrm{Xu}$ et al., 2014). 
Among them, global diffusion of culture has attracted more attention due to its power in determining images of nations and expanding consumer market globally. The current studies examine cultural diffusion in a various fields. The researches include music, sports, fashion, tourism and so on (Xu et al., 2014; Furmanovsky, 2008; Kaufman and Patterson, 2005; Crane, 1999).

According to Ko et al., (2014), The Korean Wave is influenced by the media and television has been an important media mechanism through which provides continuous access to the Korean Wave. And the advance of new media technology speeds up the cultural diffusion. The world wide web and advanced internet technologies make the speed of cultural diffusion faster. The role of video-sharing sites such as YouTube and mobile social media supports a decentralized file sharing system for culture to spread through interpersonal contacts. These platforms play an important role in the diffusion of music such as rock and K-Pop (Korean pop song) (Jung and Shim, 2013).

This study examines cultural diffusion phenomenon, including Korean Wave product such as T.V drama and tourism. Korean wave has attracted both Asian audiences and researchers' attention due to its importance in shaping national image and its potential to influence the national economy.

\subsection{The Advance of Korean Wave}

The Korean Wave refers to the cultural phenomenon in which people in the world are willing to adopt and consume Korean popular culture (Jung, 2006). The Korean Wave is the term coined by the Chinese media for the first time to describe the sudden surge in the popularity of Korean culture in China in 2002 (Hogarth, 2013).

The Korean Wave usually includes Korean music, dramas, films and games and is a hot cultural change and trend especially in Asian nations today. Korean television drama has been the one of the most important initiators for the Korean Wave. Also, the impacts of Korean Wave are dominant in the tourism. According to $\mathrm{Yu}$ et al., (2012), the Korean Wave has played an important role in the steady increase in foreign tourism in Korea.

To understand the Korean Wave's popularity, it's important to know that Asian people are looking for their self identity today. Among many nations, especially in China people began to turn their attention towards Asia for cultural inspiration and Korean drama satisfied those Chinese consumers very successfully until now (Park, 2010).

Also, the Korean Wave's success can be found in the quality of the contents. Hogarth (2013) insisted that the success factors of Korean drama were high quality, beauty, Asian-ness, the combination of modernity and tradition, cheap copy, skillful storytelling, human theme, and the modern images of male and female.

However, personal attractiveness and power of Korean stars can not be ignored. A fair attentions should be paid to the individual Korean stars who are very well known celebrities in the most Asian region. Their personal attractiveness and reputation get many Asian consumers in front of television. As a result, without analyzing the famous Korean star's influence, it is not possible to understand the Korean Wave trend. The love of the Korean Wave fans toward Korean actors, singers, and entertainers are explained by using the concept such as celebrity worship. According to McCutcheon et al., (2002), celebrity worship apparently is a significant behavioral phenomenon that dominates some people's lives. Korean stars are idols to be worshiped by Asian people today. 


\section{Korean Wave and Consumer Behavior}

The cultural trends usually give tremendous impacts to the market. Pop culture has been one of the topics of analyses in consumer research because it operates as a transmitter of marketplace ideologues (Hirschman, 1990). Many researches proved that the Korean Wave also has positive effects on exports of Korean products and increased tourism (Pang et al., 2007). They insist that the adoption of the Korean Wave can directly influence the purchase of Korean products. The consumer products related to Korean culture such as tourism, contents, cosmetic products can be influenced (Yu et al., 2012). Lee (2007), Kim and Park (2004) found the positive and significant relationship between the Korean Wave and attitude toward Korean products. Foreign consumers who are familiar with Korean culture are likely to have a more positive attitude toward Korean products and actually purchase them.

Pearce et al., (2003) suggests a five-phase model of site sacralization to describe sequential phases marked by tourists' different perceptions of tourist icon. According to the model, a cultural trend can be a source of commercial success through strategic approach. The phases are as bellows.

1. Resource identification stage: Business may seek to associate their products with famous individual.

2. Marketing emphasis stage: Business identifies the target market for the promotion of the icon, and analyze the icon's feature and attribute.

3. Interpretation stage: Business provides tourists with a sense of personal connection to enhance appreciation of the rich and varied roles which the icon occupies.

4. Sales and merchandising stage: Tourists buy the related products.

5. Broader community uses stage: The on-site population establishes a commitment to the icon as a tourist attraction.

Also, most Korean Wave stars are said to be among the highest paid entertainers outside of U.S. (Hogarth, 2013) and Asian market appears to be the direct influence of Korean stars who not only frequently appear in the media with their prestigious brands, but also regularly donates their possessions to bazaars for fundraising (Hong and Kim, 2013). As a product endorser and brand ambassador, they play an important role to spread Korean product to the global market today.

\section{Conceptual Model}

There has been an academic interest in celebrities and how they affect consumer attitude and behavior. For instance, Hogarth (2013) insists that beauty is a leading factor of the Korean Wave. Attractive and young Korean stars with gorgeous fashion and make-up in the television drama delight the viewers. McColl and Truong (2013) insist that attractiveness and beauty plays a positive effect in many domains. They hypothesize that the attractiveness of salespeople can give a positive effect on the company's overall performance. Hence, hypothesis 1 is proposed as follows.

H1. Attractiveness of Korean star (ATT) will positively affect satisfaction about the drama (SAT).

Ch'oe (2007) insists that skillful storytelling of the Korean drama grip the viewers. The stories are constructed so skillfully that the viewers result in higher reliability toward the actors in the drama. Lee (2015) identifies the positive relationship between the reliability of pop star and drama satisfaction. In the advertising study, Lafferty et al., (2002) insists that endorser credibility can be one of the variables that consumers use to judge the advertisement their satisfaction 
level. Endorser credibility is positively and strongly related to the consumer attitude. Hence, hypothesis 2 is proposed as follows.

H2. Credibility of Korean star (CRD) will positively affect satisfaction about the drama (SAT).

According to Wang et al., (2009), fans are willing to have a positive attitude when their cultural stars are related. The social identity theory is used to explain the phenomenon. Identification is a fan's emotional connection or attachment to a related object (Madrigal 2001) and people would be satisfied by a television drama because of the sense of identification. Hogarth (2013) insists that 'Asian-ness' is a major reason of the Korean Wave's popularity in East Asian countries. The all-Asian cast with modern images has an immediate appeal to television, drama viewers because of their physical, cultural similarities. The viewers feel as comfortable with the Korean drama as with those made in their own country because the drama reflects something that average Asian viewers can understand and share: Confucianism, sibling love, and oriental culture. Hence, hypothesis 3 is proposed as follows.

H3. Connectedness of Korean star (CON) will positively affect satisfaction about the drama (SAT).

According to the TPB (Theory of Planned Behavior), a consumer's behavior is directly influenced by his motivation and intention (Ajzen, 2002). Neshat et al., (2013) studied the relationship between consumer involvement and consumer attitude through a survey method. The outcome was that high involvement could develop a sense of attachment to the brand that would lead them to experience satisfaction. Hence, hypothesis 4 is proposed as follows.

H4. Involvement of audience (INV) will positively affect satisfaction about the drama (SAT).

A number of researchers have studied the relationship between commitment and satisfaction. For instance, Ligas (2008) insists that consumer commitment has strong relationships with satisfactory outcomes. Spake and Bishop (2009) insist that commitment can impact the customer's positive attitude and intention to remain. These associations have been previously explored in many different business domains (Crutchfield et al., 2001). Hence, hypothesis 5 is proposed as follows.

H5. Commitment of audience (COM) will positively affect satisfaction about the drama (SAT).

The previous studies have focused on the mediating role of positive attitude in the relationship between perception and behavior. Several researchers have identified the possibilities that good movies and dramas could be a driving force behind tourist visit (Kim and Richardson, 2003; Riley et al., 1998). The driving force to see the famous place in the movie or drama is termed the tourist 'gaze' (Urry, 1990). Tourist go to the famous destinations in order to gaze filming locations connected with movie, television, and novels. Riley et al., (1998) insist the concept of the tourist icon which serves as the focus of a visit to a tourist destination. They examined the influence of movies as tourist icon and concluded that locations in the movie witnessed increases in tourism. Kassarjian (1971) insisted that friendly attitude of consumers can explain their behavior successfully. The Korean Wave phenomenon has induced Asian consumers' interest in Korea, including fashion, 
food, product and tourism among many others ( $\mathrm{Yu}$ et al., 2012). As a result, the more Korean television drama satisfies consumers, the more consumers are likely to decide to go to Korea. Hence, hypothesis 6 is proposed as follows.

H6. Satisfaction about the drama (SAT) will positively affect revisit intention of Korea (VIS).

In this study, we developed a conceptual model that Korean stars' characteristics and foreign fan's traits affect their satisfaction and visit intention as follows.

[1] Korean Star Characteristic

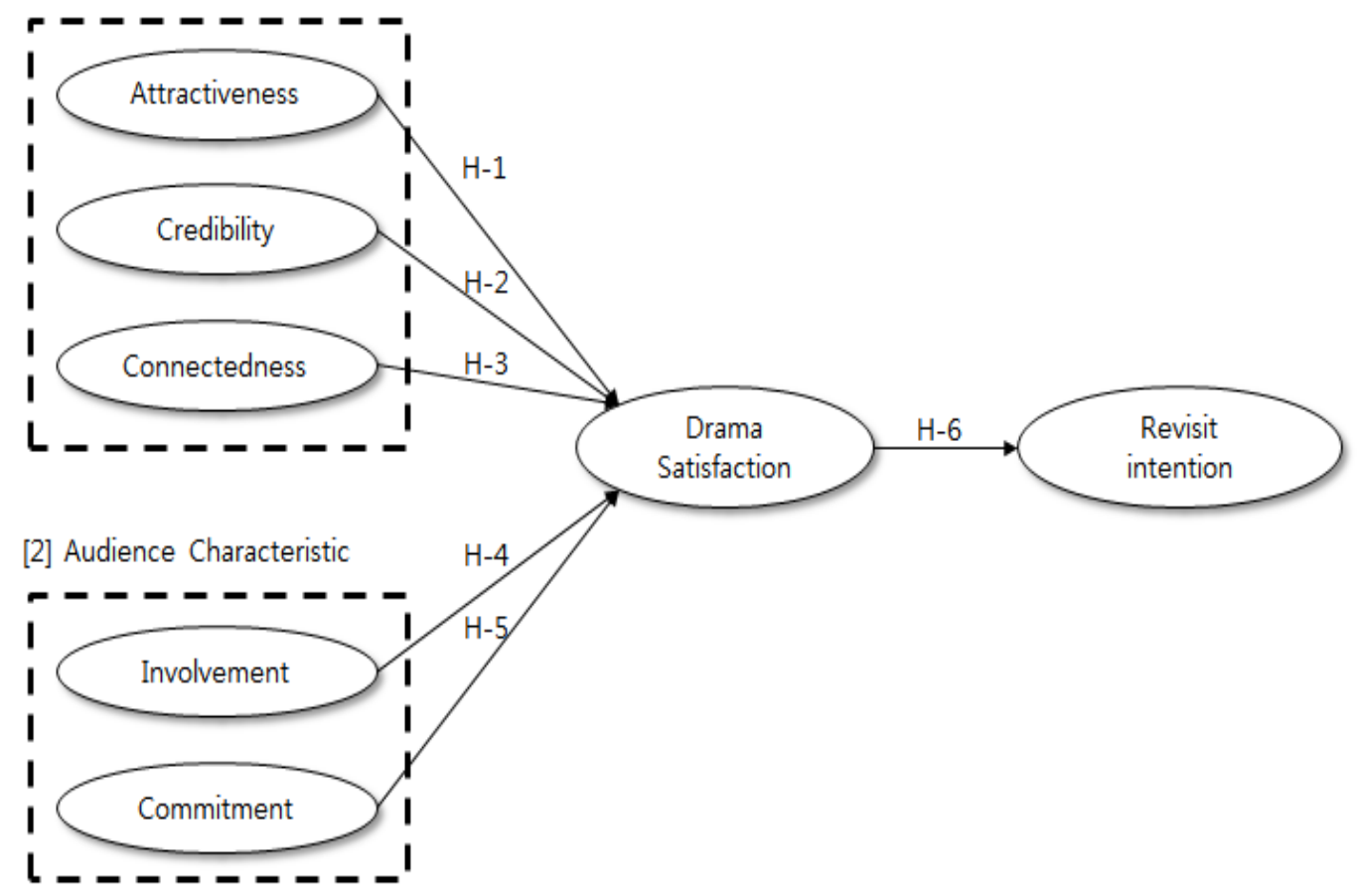

Figure 1. Proposed Research Model

\section{Research Process}

The research model developed on the basis of the hypothesis needs to be validated empirically using a quantitative research method. To do this, a face-toface questionnaire was used to collect data from the Chinese respondents who were visiting Korea during the winter vacation season in 2015.

After a review of all responses, 137 questionnaires are considered to be proper and valid for further analysis. Only the respondents who have been exposed to Korean dramas more than one time are selected for the purpose of the research. In the sample, $10.9 \%$ are male and $81.9 \%$ are female. In the age group analysis, it is found out that most of the samples are less that 30 years old $70.8 \%$ are under 29 years old and only $29.2 \%$ are over 30 years old. The samples are relatively well educated people. $72.2 \%$ are college graduates and $21.9 \%$ were graduated from graduate school. 


\section{Research Result}

Before the hypothesis test, the constructs of the questionnaire are tested for two psychometric properties: validity and reliability. Validity is the degree to which the items measure the construct, whereas reliably evaluates the stability of the measurements (Churchill, 1979).

To secure initial content validity, measures of all construct were borrowed from the related research and modified and translated into Korean. Also, to test the reliability and validity of the measures again, factor analysis and Cronbach's alpha test are performed. A higher Cronbach's alpha score indicates greater reliability and its acceptable lower limit is 0.7 (Nunnally and Bernstein, 1994). In our research, the alpha scores are between 8.08 and 9.34. Convergent validity and discriminant validity obtained from factor analysis results.

The analysis examines the interrelationships among variables and explains these variables in terms of common underlying dimension (Zhang et al., 2000). In the factor analysis, we use principal component analysis (PCA) with VARIMAX rotation option and identifies five factors that explain $70.6 \%$ of total variance. Table. 1 shows the combination of the results of the Cronbach's alpha analysis and the factor analysis.

Table 1. Reliability and Validity Test

\begin{tabular}{|c|c|c|c|c|c|c|}
\hline Factor & Variable & ATT & CRD & $\mathrm{CON}$ & $\mathrm{COM}$ & INV \\
\hline \multirow{11}{*}{$\begin{array}{c}\text { Attractiveness } \\
\text { (ATT) }\end{array}$} & Att1 & .859 & .156 & .079 & .083 & .038 \\
\hline & Att2 & .855 & .109 & -.039 & -.061 & .098 \\
\hline & Att3 & .816 & .050 & .141 & -.078 & .070 \\
\hline & Att4 & .797 & .202 & .126 & -.005 & .171 \\
\hline & Att5 & .727 & .391 & -.006 & -.088 & .207 \\
\hline & Att6 & .693 & .372 & .114 & .138 & .033 \\
\hline & Att7 & .690 & .258 & .081 & .156 & .084 \\
\hline & Att8 & .673 & .056 & -.123 & .265 & .162 \\
\hline & Att9 & .659 & .240 & .142 & .366 & .107 \\
\hline & Att10 & .611 & .202 & .098 & .349 & .088 \\
\hline & Att11 & .608 & .377 & .291 & -.035 & .073 \\
\hline \multirow{5}{*}{$\begin{array}{l}\text { Credibility } \\
\text { (CRD) }\end{array}$} & Rel1 & .206 & .865 & .104 & .195 & .038 \\
\hline & Rel2 & .179 & .860 & .082 & .058 & .160 \\
\hline & Rel3 & .193 & .835 & .091 & .012 & .079 \\
\hline & Rel4 & .330 & .804 & .124 & .054 & .035 \\
\hline & Rel5 & .338 & .776 & .152 & .180 & .006 \\
\hline \multirow{4}{*}{$\begin{array}{l}\text { Connectedness } \\
\qquad(\mathrm{CON})\end{array}$} & Con1 & .078 & .183 & .802 & .186 & .054 \\
\hline & Con2 & -.035 & .071 & .766 & .016 & .144 \\
\hline & Con3 & .170 & .133 & .741 & .319 & .115 \\
\hline & Con4 & .156 & .068 & .676 & .201 & .193 \\
\hline \multirow{3}{*}{$\begin{array}{c}\text { Commitment } \\
\text { (COM) }\end{array}$} & Com1 & .015 & .119 & .241 & .778 & .237 \\
\hline & Com2 & .083 & .104 & .382 & .778 & .145 \\
\hline & Com3 & .206 & .131 & .143 & .638 & .411 \\
\hline Involvement & Inv1 & .128 & -.006 & .188 & .192 & .854 \\
\hline
\end{tabular}




\begin{tabular}{|c|c|c|c|c|c|c|}
\hline \multirow{2}{*}{$(\mathrm{INV})$} & Inv2 & .166 & .062 & .163 & .290 & .813 \\
\cline { 2 - 7 } & Inv3 & 0.311 & 0.324 & 0.218 & 0.133 & 0.66 \\
\hline Cronbach' s alpha & 9.34 & 9.31 & 8.08 & 8.33 & 8.22 \\
\hline Igen value & 10.16 & 13.02 & 2.32 & 1.42 & 1.05 \\
\hline \% of variance & $39.07 \%$ & $13.02 \%$ & $8.95 \%$ & $5.49 \%$ & $4.04 \%$ \\
\hline Total variance & \multicolumn{5}{|c}{$70.60 \%$} \\
\hline
\end{tabular}

After the reliability and validity are tested, the hypothesis analysis is performed using path analysis. In the results, we find that the effects of ATT, CRD, COM on the SAT are significant at the 95\% confidence level supporting H1, H2, H5, and H6 respectively. However the relationships between CON, INV and SAT are not supported.

Table 2. Path Analysis Result

\begin{tabular}{|c|c|c|c|c|c|c|c|}
\hline No. & \multicolumn{3}{|c|}{ Hypothesis } & $\begin{array}{c}\text { B } \\
\text { (Standard }\end{array}$ & S.E & $\mathrm{p}^{*}$ & fit \\
\hline H1 & ATT & $\rightarrow$ & SAT & $.387(.301)$ & .093 & $.000 *$ & \multirow{6}{*}{$\begin{array}{l}\mathrm{X} 2=17.707(\mathrm{~d} . \mathrm{f}=5), \\
\mathrm{p}=.003, \\
\mathrm{GFI}=.966, \mathrm{CFI}=.965, \\
\mathrm{NFI}=.954, \\
\mathrm{RMR}=.027, \\
\text { RMSEA }=.137\end{array}$} \\
\hline $\mathrm{H} 2$ & CRD & $\rightarrow$ & SAT & $.323(.292)$ & .077 & $.000 *$ & \\
\hline $\mathrm{H} 3$ & $\mathrm{CON}$ & $\rightarrow$ & SAT & $\begin{array}{c}-.016 \\
(-.016)\end{array}$ & .067 & $.812 *$ & \\
\hline $\mathrm{H} 4$ & INV & $\rightarrow$ & SAT & $.073(.082)$ & .067 & $.273 *$ & \\
\hline H5 & $\mathrm{COM}$ & $\rightarrow$ & SAT & $.278(.313)$ & .065 & $.000 *$ & \\
\hline H6 & SAT & $\rightarrow$ & VIS & $.698(.591)$ & .082 & $.000^{*}$ & \\
\hline
\end{tabular}

\section{Conclusion}

The theoretical contribution of this research lies in connecting the television drama satisfaction to the consumer behavior such as intention to revisit. Koran drama is leading globalization of Korean pop culture as a form of the Korean Wave today. Through the research, we can conclude that Korean star's major characteristic can be a source of a fan' $\mathrm{s}$ attitude towards Korean television drama. Korean drama fans in China believe that Korean stars are attractive and reliable and those personal characteristics affect satisfaction.

This study also shows that commitment is a determinant of satisfaction. Also, it is possible to conclude that the Korean Wave can boost tourism because satisfied consumer will select Korea as their tourist attraction. 
However the influence of connectedness is not significant. These unsupported hypotheses can be explained in many different ways. But it implies a possibility very strongly that Chinese fans are looking for something different when they hail for Korean stars.

This study has limitations. First, the research relied on data acquires by Chinese tourist who visited Korea. There are issues inherent in this sampling approach. One issue is the accuracy of data because those respondents could be a group that is in favor of Korea. Second, It is not clear that those respondents selected to watch Korean drama by themselves because television is not a personal medium. There are possibilities that other family members select the channel and the respondents are not an active audience.

These limitations provide interesting direction for future research. First, the future analysis should differentiate respondents based on their prior experience of the visit or level of knowledge about Korean culture. This study needs to consider the impacts of age to Korean Wave. According to Raviv et al., (1996), the impact of sports figure or pop star usually decreases in intensity with age. As a result the impact of Korean Wave can be different depending on the age group of consumer.

Also, there are backlashes and skepticism about the Korean Wave's long-term future. For instance, anti Korean Wave movement can be found in Japan and China today. It would be necessary to consider these negative sides of the Korean Wave in the future research model.

\section{References}

[1] G. A. Churchill Jr., “A Paradigm for Developing Better Measures of Marketing Constructs”, Journal of Marketing Research, vol. 16, no. 1, (1979), pp. 64-73.

[2] D. Crane, "Diffusion Models and Fashion: A Reassessment", The Annals of the American Academy of Political and Social Science, vol. 56, no. 6, 1, (1999), pp. 13-24.

[3] T. N. Crutchfiels, V. B. Eveland, and A. P. Eveland, "Assessing Medicaid Patients", Perceptions of the OB/GYN-patient Relationship", Health Marketing Quarterly, vol. 19, no. 4, (2002), pp. 21-37.

[4] D. F. Spake, and J. S. Bishop, "The Impact of Perceived Closeness on the Differing Roles of Satisfaction, Trust, Commitment, and Comfort on Intention to Remain with a Physician", Health Marketing Quarterly, vol. 26, (2009), pp. 1-15.

[5] M. Furmanovsky, "American Country Music in Japan: Lost Piece in the Popular Music History Puzzle", Popular Music and Society, vol. 31, no. 3, (2008), pp. 357-372.

[6] E. C. Hirschman, "Secular Immortality and the American Ideology of Affluence", Journal of Consumer Research, vol. 17, no. 1, (1990), pp. 31-42.

[7] H. K. Hogarth, "The Korean Wave: An Asian Reaction to Western-dominated Globalization", Perspectives on Global Development and Technology, vol. 12, (2013), pp. 135-151.

[8] S. Hong and C.-H. Kim, "Surfing the Korean Wave", Qualitative Market Research, vol. 16, no. 1, (2013), pp. 53-75.

[9] H. S. Jung, "The Effects of Consumers Perception of Korean Wave on Korean Product Purchase and Country Image in Chinese Market”, Journal of Consumer Studies, vol. 17, no. 3, (2006), pp. 79-102.

[10] S. Jung and D. Shim, "Social Distribution: K-Pop Fan Practices in Indonesia and the Gangnam Style in South Korea", International Journal of Cultural Studies, vol. 17, no. 5, (2013), pp. 485-501.

[11] H. Kassarjian, "Incorporating Ecology into Marketing Strategy: The Case of Air Pollution", Journal of Marketing, vol. 35, (1971), pp. 61-65.

[12] J. Kaufman and O. Patterson, "Cross-national Cultural Diffusion: The Global Spread of Cricket", American Sociological Review, vol. 70, no. 1, (2005), pp. 82-110.

[13] H. Kim and S. L. Richardson, "Motion Picture Impacts on Destination Images", Annals of Tourism Research, vol. 30, no. 1, January, (2003), pp. 216-237.

[14] J. Kim and K. S. Park, "The Analysis of the Effects of Haliu Pheonomenon on the Chinese Young Generation's Fadhion Style", Journal of the Korean Society of Clothing and Textiles, vol. 28, no. 1, (2004), pp. 154-164.

[15] N. C. Ko, J.-N. Kim, S. I. No, and R. G. Simoes, "The Korean Wave Hallyu in Looking at Escapism in Peruvian Society", Perspectives on Global Development and Technology, vol. 13, (2014), pp. 332-346.

[16] B. A. Lafferty, R. E. Goldsmith and S. J. Newell, "The Dual Credibility Model: The Influence of Corporate and Endorser Credibility on Attitudes and Purchase Intentions", Journal of Marketing Theory \& practice, vol. 10, no. 3, (2002), pp. 1-12. 
[17] O. Lee, "Does the Korean Wave Bring About Country-of-origin Effect?", Journal of Korea Trade, vol. 32, no. 5, (2007), pp. 405-426.

[18] W.-J. Lee, "Korean Stars on the TV Drama and Their Influence to Foreign Fan's Behavior", Advanced Science and Technology Letters, vol. 102, (2015), pp. 79-82.

[19] M. Ligas, "The Moderating Influence of Communal Versus Exchange Relationships on a Model of Consumer Commitment in Service", Society for marketing Advances Proceedings, (2008), pp. 284-285.

[20] R. Madrigal, "Social Identity Effects in a Belief-Attitude-Intentions Hierachy: Implications for Corporate Sponsorship", Psychology \& Marketing, vol. 18, no. 2, (2001), pp. 145-165.

[21] R. McColl and Y. Truong, "The Effects of Facial Attractiveness and Gender on Customer Evaluations During a Web-Video Sales Encounter”, Journal of Personal Selling \& Sales Management, Winter, vol. 33, (2013), pp. 117-128.

[22] L. E. McCutcheon, R. Lange and J. Horn, "Conceptualization and Measurement of Celebrity Worship", British Journal of Psychology, vol. 93, (2002), pp. 67-87.

[23] C. Neshat, M. Omid and B. M. Ahmad, "The Study of the Relationship between Consumer Involvement and Purchase Decision”, Interdisciplinary Journal of Contemporary Research in Business, vol. 4, no. 12, (2013), pp. 276-296.

[24] P. L. Pearce, A. M. Morrison and G. M. Moscardo, "Individuals as Tourist Icons: A Development and Marketing Analysis", Journal of Hospitality \& Leisure Marketing, vol. 10, no. 1/2, pp. 63-85.

[25] A. Raviv, D. Bar-Tal, A. Raviv and A. Ben-Horin, "Adolescent idolization of Pop Singers: Causes, Expressions, and Credibility", Journal of Youth and Adolescence, vol. 25, (1996), pp. 631-650.

[26] R. W. Riley, D. Baker, V. Doren and S. Carlton, "Movie Induced Tourism", Annals of Tourism Research, vol. 25, no. 4, October, (1998), pp. 919-935.

[27] C. Wang, C. Chen, S. Yang and C. Farn, "Pirate or Buy? The Moderating Effect of Idolatry", Journal of Business Ethics, vol. 90, (2009), pp. 81-93.

[28] H. Yu, C. Kim and H. Kim, "Investigating Cosmetic Purchase of International Tourists in South Korea", International Journal of Management Cases, vol. 14, no. 1, (2012), pp. 398-410.

[29] W. W. Xu, J. Y. Park and H. W. Park, "The Networked Cultural Diffusion of Korean Wave", Online Information Review, vol. 39, no. 1, (2014), pp. 43-60.

[30] Z. Zhang and A. Waszink, "An Instrument for Measuring TQM Implementation for Chinese Manufacturing Companies", International Journal of Quality \& Reliability Management, vol. 17, no.7, (2000), pp. 730-755.

[31] H. Ch'oe, "The Stroytelling of the Korean Wave Dramas", Seoul: Taemunsa, (2007).

[32] Ch. Pang, H. Ungyong, "The Korean Wave and Cultural Cpmmunication", Seoul: Communication Books, (2007)

[33] C. Park, "Hakkyu-ui Hunghaeng Yujunja Mim (The Meme of Hereditary Entertainment Genes in Hallyu)", Seoul: Pubukso, (2010).

[34] J. C. Nunally and I. H. Bernstein Psychometric Theory, New York: McGraw-Hill, (1994).

[35] J. Urry, “The Tourist Gaze: Leisure and Travel in Contemporary Societies”, London: Sage, (1990).

\section{Author}

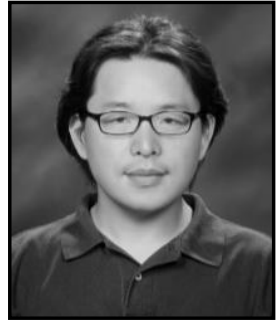

Won-jun, Lee, he received a Master degree (1996) and a Ph.D. in Marketing (2005) at the Seoul National University. He is currently an associate professor of Business Management at Cheongju University in Korea. His research areas are technology marketing, consumer behavior and e-WOM communication. 
International Journal of $u-$ and e- Service, Science and Technology Vol.8, No. 11 (2015) 